\title{
Comprehensive assessment of the efficiency of high-rise construction projects in the form of urban blocks
}

\author{
Alexandr Orlov $^{1 *}$, Irina Chubarkina ${ }^{1}$ \\ ${ }^{1}$ Moscow State University of Civil Engineering, 129337, Yaroslavskoye shosse, 26, Moscow, Russia
}

\begin{abstract}
The paper is dedicated to main modern trends in the area of high-rise construction. The classification of buildings and structures by height is given. Functional distribution by the height of buildings is presented. A review of positive and negative aspects of high-rise construction from the economic point of view is given. On the basis of the data obtained, it is proposed to build up residential microdistricts in the form of urban blocks. A plan of microdistricts development is presented. It takes into account urban blocks and includes their main characteristics. An economic and mathematical model was developed to carry out a comprehensive assessment of the effectiveness of high-rise construction projects.
\end{abstract}

\section{Introduction}

The purpose of this paper is to assess the efficiency of high-rise construction projects presented by urban blocks taking into account the social aspect of construction. Also, the need to study positive and negative factors affecting further development of the city's infrastructure and social and psychological well-being of the city's inhabitants is actualized in it.

In recent decades, a steady increase in the urban population has been observed throughout the world, which results in an increase in both the number of cities and population size. The data provided by the United Nations Organizations (UNO) confirm this trend. As a result cities and their residents face economic, social, environmental, urban planning, transport and other problems $[1,2]$. And in this case the problem of urban areas rapid growth, their territorial "proliferation" directly related to an increase in the urban population size enters into the picture [3].

In this situation, due to the growth of cities, specialists are in search for new urban planning, space planning, environmental, economic, and social solutions. "Smart growth of cities" is among the trends. It means creation of so-called "compact cities", which allow to get more compact planning, to form a comfortable modern living environment without increasing the territory of a city.

\footnotetext{
*Corresponding author: alor333@gmail.com
} 
This is primarily achieved through sound and well thought-out multipurpose skyscraper concentration. Residential bildings, offices, hotel complexes, cultural and social services system, etc. are presented in its space-planning structure [4-6].

The search for rational solutions of a "compact modern city" is conducted in various urban planning and space planning areas. Such approaches as urban densification and development of new territories are considered, and the main objective is to create compact residential areas to reduce the cost of expensive utility systems caused by their length and operation, cut the travel time from places of residence to places of employment and back [7-9].

Classification of buildings and structures by height is shown in Figure 1.

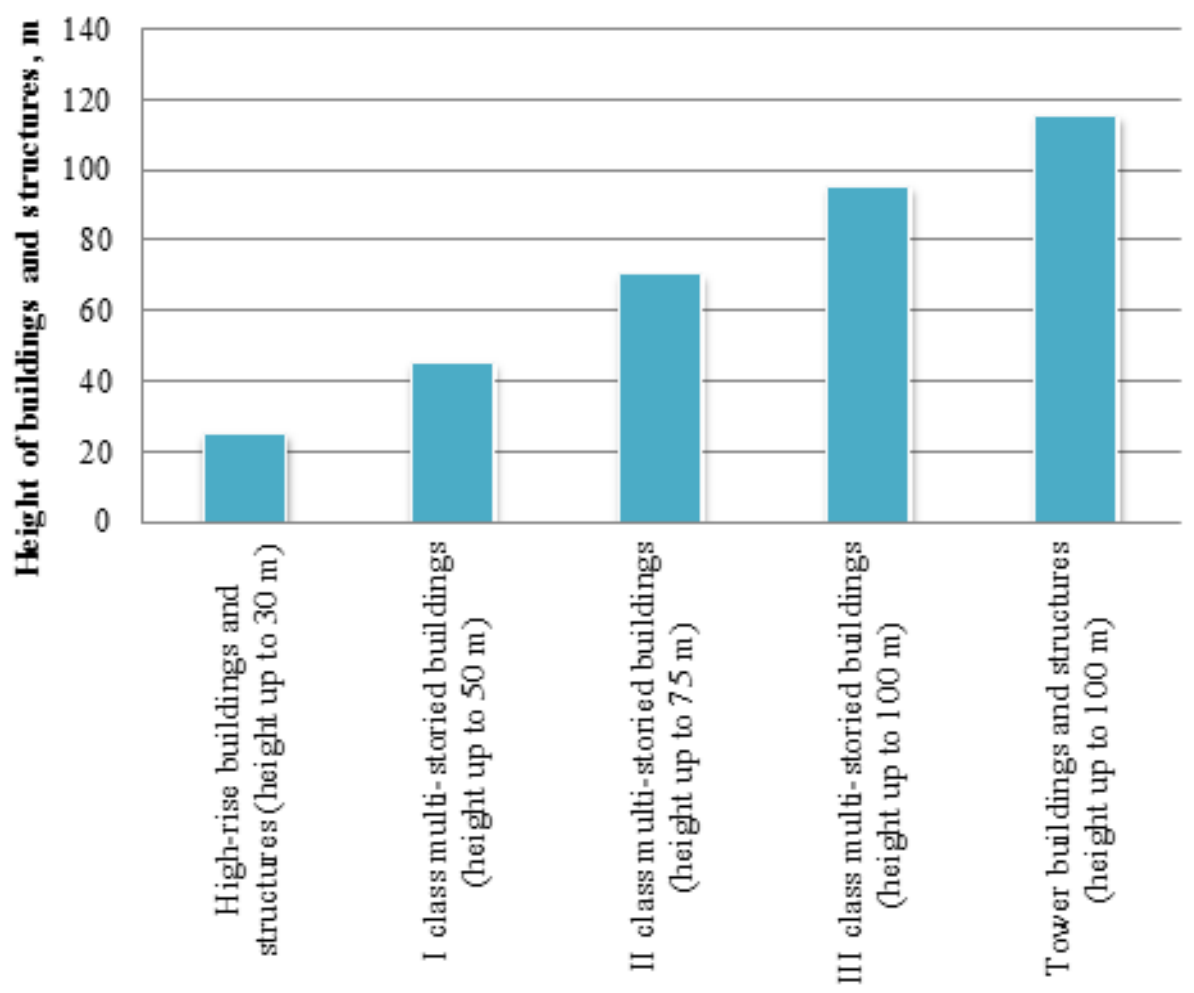

Fig. 1. Classification of buildings and structures by height.

The criterion of height in meters, but not the number of storeys, is used for the classification of skyscrapers, since storeys differ in height depending on the purpose of the building and the requirements of national design regulations.

A modern city can not be imagined without high-rise buildings for business and living. They strive to make high-rise buildings universal and expand their purpose by giving them a different form, dividing them into functional areas [10]. Multifunctionality of high-rise buildings is an economic necessity.

\section{Materials and Methods}

The methodological basis for the research is complex analysis, a system approach, and general scientific methods: analysis and synthesis; induction and deduction; comparison. Methods of grouping, sociological research, expert assessments and statistical processing of information were used in the course of the research. 
High-rise buildings all over the world refer to objects of high level responsibility and reliability. That is why the cost of their construction is much higher as compared to conventional buildings, and it is caused by technological and constructive factors, as well as other factors ensuring safe presence of people indoors [11].

When designing high-rise buildings, it is necessary to take economically justified technical decisions without compromising the reliability of a structure [12]. Distribution of functions by height presented in Fig. 2 is the most wide-spread in the area of multifunctional high-rise buildings construction.

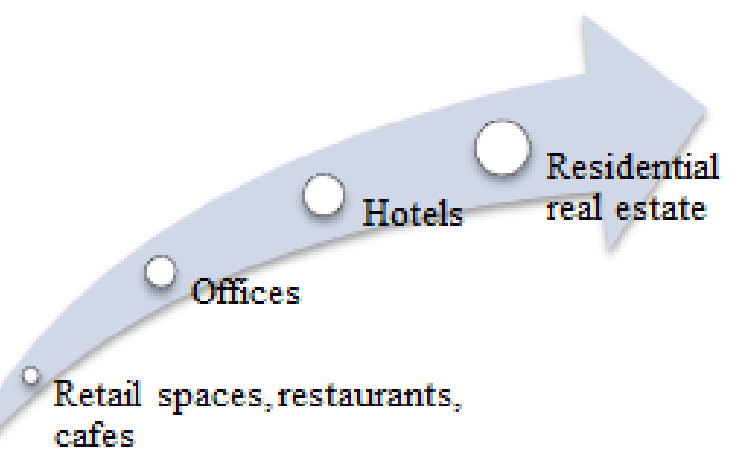

Fig. 2. Functional distribution of buildings by height.

As is seen from Figure 2, the most common type of construction objects by the functional distribution is residential real estate. However, it should be noted that at the present time consumers are not interested in purchasing apartments in residential complexes separated from social infrastructure facilities.

Social infrastructure is a system of facilities, utilities, as well as enterprises, institutions and organizations that provide social and welfare services to the population, management bodies and personnel administration, which activities are aimed at satisfying public needs of citizens that meet the established quality of life indicators. Social infrastructure unites economy, health, education, culture and art, physical education and sports, trade and public catering, personal services and contributes to the improvement of living conditions of the population. Development and effective functioning of objects that are a part of the social infrastructure, their accessibility are essential conditions for improving the standard of living and quality of life of the population $[13,14]$.

The main factors determining the development of the social infrastructure system are trends in socio-economic development of a settlement characterized by an increase in the population, development of the residential property market, and the services sector. Implementation of high-rise multifunctional complexes is targeted at the fulfillment of social conditions, and residents of these complexes will be provided with them by improving the quality and availability of social services (education, health, culture and social security) for all categories of residents.

Taking into account the individual approach to the design and construction of highrise buildings, use of exclusive elements of utility systems and equipment, as well as materials that ensure the uniqueness of the building, creates significant uncertainty in the technical and economic assessment of design decisions.

Advantages and disadvantages of high-rise construction from the economic point of view are given in Table 1. 
Table 1. Advantages and disadvantages of high-rise construction.

\begin{tabular}{|l|l|}
\hline Advantages of high-rise construction & \multicolumn{1}{|c|}{ Disadvantages of high-rise construction } \\
\hline \multicolumn{1}{|c|}{1} & \multicolumn{1}{|c|}{2} \\
\hline $\begin{array}{l}\text { Creation of additional jobs (building } \\
\text { maintenance personnel). }\end{array}$ & $\begin{array}{l}\text { Increased requirements for the provision of } \\
\text { integrated safety and security presuppose use of } \\
\text { high-quality technical solutions. }\end{array}$ \\
\hline $\begin{array}{l}\text { Economical use of urban areas under } \\
\text { conditions of an acute shortage of land and } \\
\text { its high cost. }\end{array}$ & $\begin{array}{l}\text { Constant monitoring of structures, as well as all } \\
\text { utility systems shall be carried out in high-rise } \\
\text { buildings. }\end{array}$ \\
\hline $\begin{array}{l}\text { High-rise buildings contribute to the } \\
\text { development of economy, business and } \\
\text { tourism. }\end{array}$ & $\begin{array}{l}\text { Approximately 70\% of the internal space is ussed } \\
\text { in a skyscraper; the rest space is occupied by } \\
\text { supporting structural elements, staircases and lift } \\
\text { shafts. }\end{array}$ \\
\hline $\begin{array}{l}\text { Evidence of a new stage in the development } \\
\text { of construction, the level of scientific and } \\
\text { technological development, well-being of } \\
\text { population }\end{array}$ & $\begin{array}{l}\text { Construction and operation of skyscrapers require } \\
\text { a much higher consumption of resources, which is } \\
\text { associated with excessive energy consumption } \\
\text { and colossal operating costs. }\end{array}$ \\
\hline
\end{tabular}

It is obvious that erection of high-rise buildings has both its advantages and disadvantages in terms of economic resources. So, there is a need to improve the efficiency of high-rise buildings. The decision on the implementation of an investment project requires carrying out of calculation and analysis of indicators of investment performance conducted within the framework of project analysis [15-17]. The basis for the assessment of the return on investment is the process of calculation and comparison of the required amount of costs and results from the implementation of projects.

\section{Results}

Construction of a "compact city" consisting of high-rise multifunctional buildings and service facilities creates a comfortable and convenient urban environment for the residents, and also solves problems related to the efficient use of land resources, environmental problems, etc.

Microdistricts with multifunctional high-rise buildings using a new town-building unit called "urban block" can be presented by this type of "compact city".

An urban block will be presented by multipurpose high-rise buildings (various functional groups of facilities - residential, hotel, entertainment, office, catering, trade, service, sports, etc. - will be included in the space planning structure) and a courtyard (a private area with trees and srubs, grounds for recreation and fire access roads, available primarily for residents of that particular urban block and closed for public).

A city block in this case will consist of a set of urban blocks, public areas with driveways, parking lots, recreational areas, and a block green belt.

And a microdistrict will include city blocks, streets and driveways, buildings of other functional purposes, including schools, health and fitness centers, a microdistrict center, utility facilities, recreation common areas with trees and shrubs, kindergartens, day-to-day service facilities, detached garages.

The housing project of a microdistrict in the form of urban blocks provides for a clear separation of private and public areas within a city block (Fig.3). 


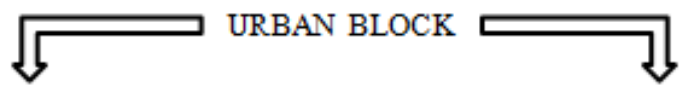

PRIVATE AREAS are allocated within an urb an block and represent courtyards with trees and shrubs, with playgrounds for young children and recreation; private areas are free from transport (except special vehicles)
PUBLIC AREAS are allocated within a city block and include driveways, parking lots, garden squares, boulevards; it is planned to allocate mainly utilitarian public areas (with driveways, parking lots, public utility sites) and pedestrian green areas

Fig. 3. Private and public areas within an urban block.

A microdistrict with urban blocks is shown in Figure 4.

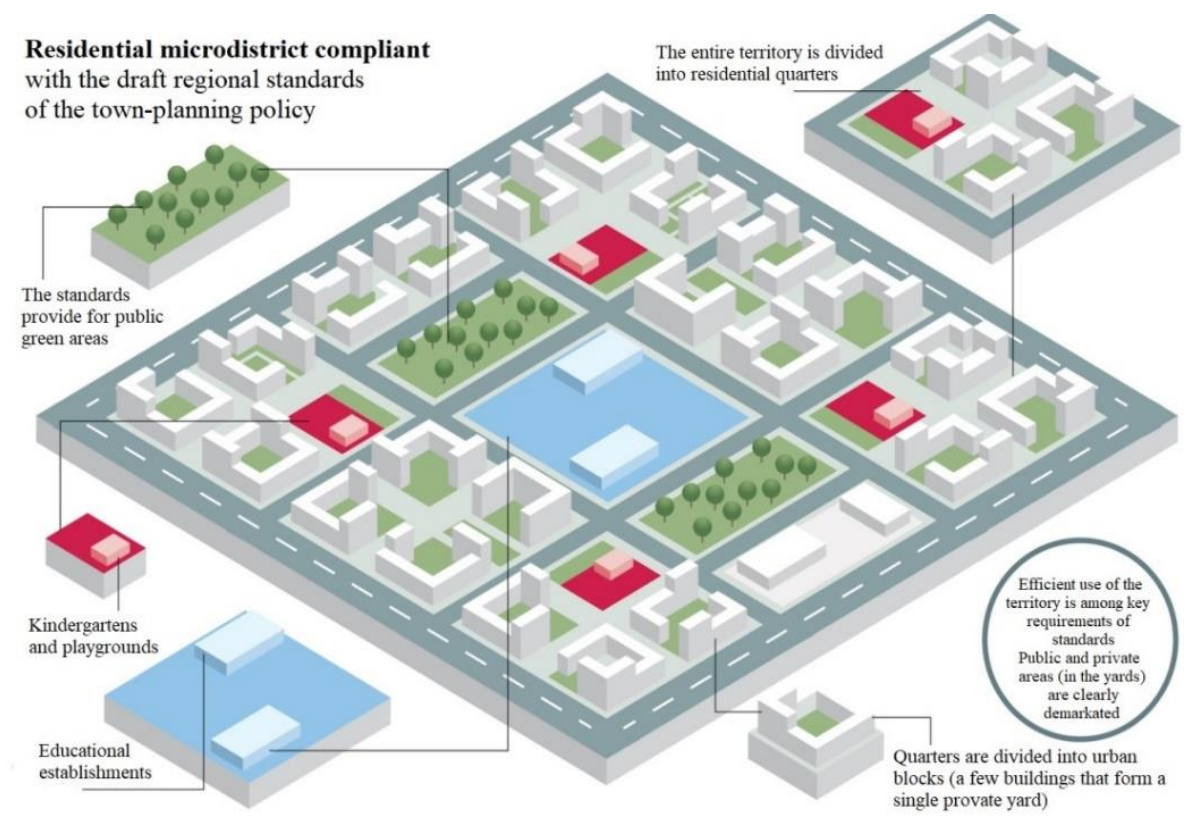

Source: Russian News (News-russia.info)

Fig. 4. A microdistrict in the form of urban blocks.

Microdistrict construction in the form of urban blocks provides for comfortable and favorable living conditions in accordance with federal urban planning, sanitary and hygienic requirements, including:

$\Rightarrow$ Availability of socially significant facilities (including schools and kindergartens), including their normative availability.

$\Rightarrow$ Creation of green courtyards free from transport (trees and shrubs).

$\Rightarrow$ Creation of full-fledged recreational green areas with all the necessary infrastructure (playgrounds, sports grounds, recreation areas) within a city block (public gardening) and a microdistrict (public use gardening).

$\Rightarrow$ Placement of trade and service facilities at street level, which allows to create a functionally saturated environment of residential streets and driveways. 
$\Rightarrow$ Profiles of streets and driveways ensuring comfortable pedestrian traffic are worked out.

$\Rightarrow$ Space planning of city blocks and urban blocks is aimed at providing a single front of development, traditional for urban spaces.

The following infrastructure elements are also provided (Table 2):

Table 2. Elements of infrastructure in a microdistrict in the form of urban blocks.

\begin{tabular}{|l|l|}
\hline $\begin{array}{l}\text { Infrastructure } \\
\text { facility }\end{array}$ & \multicolumn{1}{c|}{ Characteristics of infrastructure facilities } \\
\hline Passageways & $\begin{array}{l}\text { Passageways are divided into: } \\
\text { 1. Utilitarian, i.e. those ones including access ways, parking places for motor } \\
\text { vehicles and a public utility site; } \\
\text { 2. Recreational, i.e. those ones including access ways and grassed and } \\
\text { landscaped areas of shared use with recreational areas, playgrounds and sports } \\
\text { grounds (arrangement of appropriate driveways in the form of boulevard } \\
\text { streets with graden squares at points of their intersection) }\end{array}$ \\
\hline Playgrounds & $\begin{array}{l}\text { Playgrounds are intended for games and active recreation of children from } \\
\text { three to sixteen years }\end{array}$ \\
\hline $\begin{array}{l}\text { Microdistrict } \\
\text { landscaping of } \\
\text { shared use }\end{array}$ & $\begin{array}{l}\text { It is designed to provide the population with recreational landscaped areas. } \\
\text { Microdistrict landscaped areas of shared use represent parks, garden squares, } \\
\text { boulevards, gardens, and their borders are fixed with red lines }\end{array}$ \\
\hline $\begin{array}{l}\text { Landscaping } \\
\text { of private areas } \\
\text { (yards) }\end{array}$ & $\begin{array}{l}\text { It is designed to create a comfortable environment in residential yards and } \\
\text { ensure quiet recreation for residents }\end{array}$ \\
\hline $\begin{array}{l}\text { Landscaping } \\
\text { of public areas } \\
\text { of a city block }\end{array}$ & $\begin{array}{l}\text { It is intended for the creation of convenient pedestrian connections and to } \\
\text { ensure daily recreation for the population. Landscaping of public areas of a } \\
\text { city block is possible in the form of boulevards, garden squares, as well as } \\
\text { individual greenery islands }\end{array}$ \\
\hline Parking areas & Parking areas are designed in accordance with the transport regulations \\
\hline Dog runs & They are specially equipped and enclosed places for dogs free ranging \\
\hline $\begin{array}{l}\text { Recreation } \\
\text { areas }\end{array}$ & Recreation areas are designed for quiet recreation and table games for adults \\
\hline $\begin{array}{l}\text { Sports grounds } \\
\text { Public utility } \\
\text { sites (for dust } \\
\text { collectors) }\end{array}$ & $\begin{array}{l}\text { Sports grounds are intended for physical exercises and designed for all age } \\
\text { groups. Dimensions and planning configuration of a specific site depend on its } \\
\text { collection utility sites are places specially equipped for solid household waste }\end{array}$ \\
\hline
\end{tabular}

The most significant areas of social facilities development can be identified and longterm activities when creating social infrastructure facilities can be planned based on certain standards.

Assessment of efficiency from the construction of high-rise multifunctional complexes in the form of urban blocks is carried out based on achieved results of each main indicator by comparing their planned and actual values, and it is calculated by formula 1 . An analysis of efficiency indicators may allow to conclude whether the implementation of an investment project is a rational decision or not. Such indicators of investment efficiency include, for example, environmental, commercial, social and budgetary efficiency, as well as enterprise costs.

$$
E=\text { Nactual } / \text { Nplanned } x 100 \%
$$


where $\mathrm{E}$ is the efficiency of construction of high-rise multifunctional complexes in the form of urban blocks,

$\mathrm{N}_{\text {actual }}$ - the actual value of indicators,

$\mathrm{N}_{\text {planned }}$ - the planned value of indicators.

Values of indicators $\mathrm{N}$ are determined according to the economic and mathematical model, in which key target functions that determine the efficiency from the implementation of an investment and construction project are identified (formula 2).

$$
\mathrm{N}=\mathrm{f}(\mathrm{C}, \mathrm{E}, \mathrm{B}, \mathrm{K}, \mathrm{V}, \mathrm{Z})=\left\{\begin{array}{c}
\mathrm{NPV} \rightarrow \max \\
\mathrm{IRR} \rightarrow \max \\
\mathrm{PI} \geq 1 \\
\mathrm{PP} \rightarrow \min
\end{array}+\left\{\begin{array}{c}
\text { Economic efficiency }(\mathrm{E}) \rightarrow \max \\
\text { Budgetary efficiency }(B) \rightarrow \max \\
\text { Commercial efficiency }(\mathrm{K}) \rightarrow \max \\
\text { Social efficiency }(V) \rightarrow \max \\
\text { Enterprise costs }(Z) \rightarrow \min
\end{array}\right.\right.
$$

where $\mathrm{C}$ is economic efficiency, a presented set of parameters such as net present value (NPV), internal rate of return (IRR), profitability index (PI), payback period (PP).

$\mathrm{E}$ is ecological efficiency, which is a measurable result of the environmental management system related to the control and organization of its environmental aspects, based on the environmental policy, as well as planned environmental indicators.

$\mathrm{B}$ is budgetary efficiency, which reflects an impact of the implementation of an investment and construction project on revenues and expenditures of the federal, regional or local budget.

$\mathrm{K}$ is commercial efficiency, defined as the difference between the inflow and outflow of cash from investments and real estate sales, taking into account payment of various charges and taxes.

$\mathrm{Z}$ is costs incurred by an enterprise, represented by a combination of resources (material, labor, financial, etc.) consumed by the construction enterprise during the reporting period.

$\mathrm{V}$ is social efficiency, which reflects the correspondence of costs and social results of the project unde consideration to the goals and social interests of its participants.

The main indicators of social efficiency during design and construction of high-rise multifunctional complexes in the form of urban blocks are as follows:

$\Rightarrow$ An increase in the life expectancy.

$\Rightarrow$ An increase in the birth rate.

$\Rightarrow$ Reduction of unemployment.

$\Rightarrow$ An increase in the level of health facilities availability.

$\Rightarrow$ An increase in the proportion of population provided with cultural facilities in accordance with the statutory values.

$\Rightarrow$ An increase in the proportion of population provided with sports facilities in accordance with statutory values.

$\Rightarrow$ An increase in the number of people systematically taking excercises and going for sports.

This calculation reflects the feasibility of project implementation and allows to hold corrective actions to be taken if unsatisfactory estimates are obtained.

\section{Conclusions}

Among the reasons that prevent from an increase in the volume of high-rise buildings construction is a relatively small experience in the construction of high-rise complexes and, as a consequence, the need to attract expensive foreign capacities; issues related to 
standartization and technical regulations for high-rise design, construction supervision, etc. remain open. However, in the long term, the demand for high-rise construction in Russia is expected to grow.

Considering the above, it can be noted that with the increase in the level of technological development and the cost of land, the disadvantages currently available may not be as big as they are now. Currently, regulatory documentation is being developed, the technology of production of some components and utility systems is being improved, and the qualification of employees is growing, which gives hope for the development of highrise construction. In general, introduction of urban blocks can improve the return on investment in the design and construction of high-rise multifunctional complexes and enhance the competitiveness of the project developer.

\section{References}

1. A. Orlov, Yu. Zhukova, Economics and Entrepreneurship, 4-2 (81-2), 979-982 (2017)

2. S. Mikhaleva, A. Orlov, a collection of materials of the International Scientific and Practical Seminar "Development of the Scientific School of Real Estate Management Theory", 111-114 (2015)

3. Y. Kog, Practice Periodical on Structural Design and Construction (2018)

4. M. Rafiei, H. Adeli, Structural Design of Tall and Special Buildings (2016)

5. A. Aminmansour, K. Moon, Journal of Architectural Engineering, 16 (2), 47-53 (2010)

6. E. Stein, MATEC Web of Conferences, 106,01036 (2017)

7. P. Love, D. Edwards, Z. Irani, IEEE Transactions on Engineering Management, 59 (4), 6032087, 560-571 (2012)

8. E. Frolova, Sotsiologicheskie Issledovaniya, 12, 51-58 (2014)

9. B. Semaan, J. Hemsley, ISCRAM 2015 Conference Proceedings - 12th International Conference on Information Systems for Crisis Response and Management, 321-328 (2015)

10. I. Ptuhina, T. Spiridonova, T. Musorina, Applied Mechanics and Materials, 725-726, 153-159 (2015)

11. Z. Su, Advanced Materials Research, 1055, 297-300 (2014)

12. P. Kostrikin, E. Buadze, Review of the Southwest State University, 1 (64), 83-92 (2016)

13. O. Tielietov, N. Letunovska, Actual Problems of Economics, 160 (1), 329-337 (2014)

14. E. Frolova, M. Vinichenko, A. Kirillov, O. Rogach, E. Kabanova, International Journal of Environmental and Science Education, 11 (15), $7421-7430$ (2016)

15. I. Ptuhina, T. Spiridonova, T. Musorina, S. Kanyukova, A. Rezvaia, MATEC Web of Conferences, 53,01049 (2016)

16. O. Kurakova, Economics and Entrepreneurship, 4-2 (81-2), 648-651 (2017)

17. S. Belyakov, Construction: science and education, 2, 2 (2015) 